\title{
STUDI KOMPARATIF USAHATANI SEMANGKA NON-BIJI PADA KELOMPOK TANI RIDHO LESTARI DI KABUPATEN BANYUWANGI
}

\author{
Mohammad Rizki Dedi ${ }^{1}$, Lenny Widjayanthi ${ }^{2}$, Sudarko $^{2}$ \\ ${ }^{1}$ Alumnus, Program Studi Agribisnis Fak. Pertanian Universitas Jember \\ ${ }^{2}$ Staf Pengajar, Program Studi Agribisnis Fak. Pertanian Universitas Jember \\ Email: rizkidedi71@gmail.com
}

\begin{abstract}
Ridho Lestari farmer group are non-seed watermelon farmer groups who have permanent members and non-permanent members. Permanent members are farmers who have land while non permanent members are the farmers who do not have their own land. They rent from other farmers. This study aims to determine income, cost eficiency, and factors that influence farmer's income. The study was conducted in the village of the district Muncar Tembokrejo districts Banyuwangi used analytical and comparative method. Sampling method used total sampling as much as 50 respondents. The data collection using interviews and literature were analyzed by income analysis, $R / C$ ratio, and multiple linear regression. The results shows that (1) There were differences income significantly between permanent members and non-permanent members (2) There were differences on cost efficiency significantly between permanent members and non-permanent members (3) Factors that significantly influence farmer's income were field cost $(R p)$, seed cost $(R p)$, pesticide cost $(R p)$, labor cost $(R p)$, sales volume $(k g)$ and the selling price $(\mathrm{Rp} / \mathrm{Kg})$.
\end{abstract}

Keywords: non-seed watermelon farm, income, cost efficiency

\section{PENDAHULUAN}

Semangka memiliki daya tarik khusus karena buahnya yang segar, mengandung kadar air lebih kurang sembilan puluh dua persen (92\%). Walaupun nilai gizinya rendah yaitu tujuh persen (7\%) karbohidrat dalam bentuk gula dan kandungan vitamin dan mineralnya pun tergolong rendah namun semangka diminati konsumen karena rasanya yang segar (Kalie, 2002).

Daerah penanaman semangka tersebar luas mulai dari wilayah Indonesia bagian barat sampai wilayah Indonesia bagian timur. Beberapa daerah sentra penanaman semangka di Indonesia antara lain Aceh, Deli Serdang, Medan, Riau, Sumatra barat, Sumatra selatan, pantai utara Jawa, pantai selatan Jawa, Malang, Pasuruan, Jember dan Banyuwangi. Sentra penanaman semangka non-biji masih terpusat di pulau Jawa terutama di Jawa Timur (Banyuwangi, Kediri, Jember), Jawa Tengah (Magelang dan Sragen), dan Yogyakarta tepatnya di daerah Kulon Progo. Banyaknya sentra penanaman semangka tersebut karena bertanam semangka memerlukan waktu relatif singkat lebih kurang 60-75 hari setelah tanam dan keuntungannya cukup besar (Prajnanta, 1999).

Banyuwangi yang terletak di ujung timur pulau Jawa merupakan sentra hortikultura buah di Jawa Timur khususnya semangka. Sentra semangka di Kabupaten Banyuwangi terletak di Kecamatan Muncar. Kecamatan Muncar selain terkenal dengan produksi ikan yang melimpah juga terkenal dengan semangkanya yang manis dan menyegarkan. Lahan pantai di Kecamatan Muncar cocok untuk bertanam semangka karena cuaca yang panas dan kondisi tanah yang berpasir. Petani semangka di Kecamatan Muncar menanam komoditas semangka sepanjang musim.

Kecamatan Muncar memiliki beberapa kelompok tani. Kelompok tani di Kecamatan Muncar rata-rata membudidayakan tanaman pangan khususnya padi. Salah satu kelompok tani di 
Kecamatan Muncar tidak membudidayakan tanaman pangan, melainkan membudidayakan tanaman hortikultura khususnya semangka dan melon. Kelompok tani tersebut adalah kelompok tani Ridho Lestari yang dipimpin oleh bapak Agus Sugiarto dan bertempat di Desa Tembokrejo. Kelompok tani Ridho Lestari fokus pada usahatani semangka dan melon karena usahatani semangka dan melon memberikan keuntungan tinggi, tetapi usahatani ini juga memiliki risiko yang tinggi. Risiko usahatani semangka yaitu gagal panen karena serangan bakteri virus, harga jual rendah, dan lain-lain. Sampai saat ini usahatani tersebut masih terus berjalan dengan baik dan secara konsisten menanam semangka sepanjang tahun.

Kelompok tani Ridho Lestari merupakan satu-satunya kelompok tani yang membudidayakan tanaman semangka. Adanya kondisi pendapatan usahatani semangka yang tinggi menyebabkan banyak petani lain mengikuti usaha tani semangka dan melon kemudian bergabung dengan kelompok tani Ridho Lestari. Banyaknya petani lain bergabung dalam keanggotaan Ridho Lestari sehingga Kelompok tani ini memiliki keanggotaan tetap dan tidak tetap. Anggota tetap adalah petani yang memiliki lahan untuk usahatani semangka sedangkan anggota tidak tetap adalah petani yang tidak memiliki lahan sendiri kemudian menyewa lahan untuk usahatani semangka dan bergabung dalam kelompok tani Ridho Lestari. Petani anggota tetap dan tidak tetap secara teknis memperoleh informasi yang sama. Perbedaan keduanya terkait status lahan yang digunakan untuk usahatani semangka.

Tujuan penelitian ini adalah untuk mengetahui (1) perbedaan pendapatan usahatani semangka antara anggota tetap dan tidak tetap pada kelompok tani Ridho Lestari di Desa Tembokrejo Kecamatan Muncar Kabupaten Banyuwangi (2) perbedaan efisiensi penggunaan biaya usahatani semangka antara anggota tetap dan tidak tetap kelompok tani Ridho Lestari di Desa Tembokrejo Kecamatan Muncar Kabupaten Banyuwangi. (3) faktor-faktor yang berpengaruh terhadap pendapatan usahatani semangka pada kelompok tani Ridho Lestari di Desa Tembokrejo Kecamatan Muncar Kabupaten Banyuwangi.

\section{METODE PENELITIAN}

$\begin{array}{cll}\text { Penentuan } & \text { daerah } & \text { penelitian } \\ \text { ditentukan secara } & \text { sengaja } & \text { (purposive }\end{array}$ method). Penentuan daerah penelitian tersebut didasarkan pada pertimbangan bahwa di Desa Tembokrejo terdapat kelompok tani semangka yang memiliki anggota tetap dan tidak tetap. Penelitian dilakukan pada satu musim tanam yakni Bulan July-Agustus 2014. Metode yang digunakan dalam penelitian adalah metode analitik dan komparatif. Metode pengambilan contoh dalam penelitian ini menggunakan total sampling. Jumlah populasi yang sekaligus diambil sebagai sampel dalam penelitian sebanyak 50 anggota kelompok tani Ridho Lestari dengan rincian sebagai berikut:

Tabel 1. Jumlah Subjek Penelitian

\begin{tabular}{clc}
\hline No. & \multicolumn{1}{c}{ Strata } & Populasi \\
\hline 1 & Anggota tetap & 30 \\
2 & Anggota tidak tetap & 20 \\
\hline & Total & $\mathbf{5 0}$ \\
\hline
\end{tabular}

Sumber: Kelompok Tani Ridho Lestari, 2014

Untuk mencapai tujuan pertama mengenai pendapatan usahatani semangka pada kelompok tani Ridho Lestari di Desa Tembokrejo, peneliti menggunakan analisis pendapatan dengan formulasi sebagai berikut:

Keterangan:

$$
\mathrm{Pd}=\mathrm{TR}-\mathrm{TC}
$$

Pd : Pendapatan usahatani semangka pada anggota tetap dan anggota tidak tetap kelompok tani Ridho Lestari (Rp)

TR: Penerimaan usahatani semangka pada anggota tetap dan anggota tidak tetap kelompok tani Ridho Lestari (Rp)

TC: Biaya usahatani semangka pada anggota tetap dan anggota tidak tetap kelompok tani Ridho Lestari (Rp)

Kriteria pengambilan keputusan:

a. Apabila nilai $\mathrm{Pd}>0$, maka usahatani semangka pada anggota tetap dan anggota tidak tetap kelompok tani 
Ridho Lestari di Desa Tembokrejo menguntungkan

b. Apabila nilai $\mathrm{Pd}=0$, maka usahatani semangka pada anggota tetap dan anggota tidak tetap kelompok tani Ridho Lestari di Desa Tembokrejo mengalami BEP (Break Event Point)

c. Apabila nilai $\mathrm{Pd}<0$, maka usahatani semangka pada anggota tetap dan anggota tidak tetap kelompok tani Ridho Lestari di Desa Tembokrejo tidak menguntungkan.

Untuk mengetahui perbedaan pendapatan antara anggota tetap dan tidak tetap pada kelompok tani Ridho Lestari menggunakan uji beda untuk dua sampel independen. Uji beda rata-rata digunakan untuk mengetahui apakah terdapat perbedaan rata-rata pendapatan yang signifikan antara anggota tetap dan anggota tidak tetap pada kelompok tani Ridho Lestari. Formulasi uji beda rata-rata adalah sebagai berikut:

$$
=\frac{-X_{1}--X_{2}}{\sqrt{\left(\frac{\left(n_{1}-1\right) S_{1}^{2}+\left(n_{2}-1\right) S_{2}^{2}}{n_{1}+n_{2}-2}\right) x\left(\frac{1}{n_{1}}+\frac{1}{n_{2}}\right)}}
$$

dimana:

$$
S=\frac{\sqrt{\sum_{X} 2-\left(\frac{\sum X}{n}\right) 2}}{n-1}
$$

Keterangan:

$$
\begin{aligned}
& \overline{\mathrm{X}}_{1} \text { : rata-rata pendapatan usahatani } \\
& \text { semangka pada anggota tetap } \\
& \text { kelompok tani Ridho Lestari (Rp) } \\
& \overline{\mathrm{X}}_{2} \text { : rata-rata pendapatan usahatani } \\
& \text { semangka pada anggota tidak tetap } \\
& \text { kelompok tani Ridho Lestari (Rp) } \\
& \mathrm{s}_{1} \text { : standar deviasi pendapatan usahatani } \\
& \text { semangka pada anggota tetap } \\
& \text { kelompok tani Ridho Lestari } \\
& \mathrm{s}_{2} \text { : standar deviasi pendapatan usahatani } \\
& \text { semangka pada anggota tidak tetap } \\
& \text { kelompok tani Ridho Lestari }
\end{aligned}
$$

Hipotesis:

$\mathrm{H}_{0}$ : tidak terdapat perbedaan nyata pendapatan usahatani semangka antara anggota tetap dan tidak tetap pada kelompok tani Ridho Lestari

$\mathrm{H}_{1}$ : terdapat perbedaan nyata pendapatan usahatani semangka antara anggota tetap dan tidak tetap pada kelompok tani Ridho Lestari

Kriteria pengambilan keputusan:

a. Apabila $\mathrm{t}_{0} \leq \mathrm{t}_{0,05 / 2}$ maka $\mathrm{HO}$ diterima, berarti tidak terdapat perbedaan nyata pendapatan usahatani semangka antara anggota tetap dan tidak tetap pada kelompok tani Ridho Lestari

b. Apabila $t_{0}>t_{0,05 / 2}$ maka H0 ditolak, berarti terdapat perbedaan nyata pendapatan usahatani semangka antara anggota tetap dan tidak tetap kelompok tani Ridho Lestari.

Untuk mencapai tujuan kedua mengenai efisiensi penggunaan biaya usahatani semangka antara anggota tetap dan tidak tetap pada kelompok tani Ridho Lestari menggunakan analisis $\mathrm{R} / \mathrm{C}$ ratio. Analisis R/C ratio menunjukkan besarnya penerimaan yang diterima petani untuk setiap rupiah yang dikeluarkan dalam usahatani semangka. Analisis ini digunakan untuk mengetahui apakah usahatani semangka efisien atau tidak. Secara matematis dapat diformulasikan sebagai berikut:

$$
\mathrm{R} / \mathrm{C} \text { ratio }=\mathrm{TR} / \mathrm{TC}
$$

Keterangan:

TR : total penerimaan usahatani semangka pada anggota tetap dan tidak tetap kelompok tani Ridho Lestari ( $\mathrm{Rp}$ )

TC : total biaya usahatani semangka pada anggota tetap dan tidak tetap kelompok tani Ridho Lestari (Rp)

Kriteria pengambilan keputusan:

a. $\mathrm{R} / \mathrm{C}$ ratio $>1$ maka usahatani semangka pada anggota tetap dan tidak tetap kelompok tani Ridho Lestari efisien

b. $\mathrm{R} / \mathrm{C}$ ratio $\leq 1$ maka usahatani semangka pada anggota tetap dan tidak tetap kelompok tani Ridho Lestari tidak efisien

Untuk mengetahui perbedaan efisiensi penggunaan biaya usahatani antara anggota tetap dan tidak tetap pada kelompok 
tani Ridho Lestari dengan menggunakan uji beda dari dua sampel yang independen. Uji beda rata-rata digunakan untuk mengetahui apakah terdapat perbedaan rata-rata efisiensi penggunaan biaya yang signifikan antara anggota tetap dan tidak tetap pada kelompok tani Ridho Lestari. Formulasi uji beda ratarata adalah sebagai berikut:

$$
=\frac{-X_{1}--X_{2}}{\sqrt{\left(\frac{\left(n_{1}-1\right) S_{1}^{2}+\left(n_{2}-1\right) S_{2}^{2}}{n_{1}+n_{2}-2}\right) \times\left(\frac{1}{n_{1}}+\frac{1}{n_{2}}\right)}}
$$

dimana:

$$
S=\frac{\sqrt{\sum_{X} 2-\left(\frac{\sum X}{n}\right) 2}}{n-1}
$$

Keterangan:

$\overline{\mathrm{X}}_{1}$ : rata-rata efisiensi penggunaan biaya usahatani semangka pada anggota tetap kelompok tani Ridho Lestari

$\overline{\mathrm{X}_{2}}$ : rata-rata efisiensi penggunaan biaya usahatani semangka pada anggota tidak tetap kelompok tani Ridho Lestari

$\mathrm{s}_{1}$ : standar deviasi efisiensi penggunaan biaya usahatani semangka pada anggota tetap kelompok tani Ridho Lestari

$\mathrm{s}_{2}$ : standar deviasi efisiensi penggunaan biaya usahatani semangka pada anggota tidak tetap kelompok tani Ridho Lestari

$\mathrm{n}_{1}$ : jumlah sampel anggota tetap kelompok tani Ridho Lestari

$\mathrm{n}_{2}$ : jumlah sampel anggota tidak tetap kelompok tani Ridho Lestari

Hipotesis:

$\mathrm{H}_{0}$ : tidak terdapat perbedaan nyata efisiensi penggunaan biaya usahatani semangka antara anggota tetap dan tidak tetap pada kelompok tani Ridho Lestari

$\mathrm{H}_{1}$ : terdapat perbedaan nyata efisiensi penggunaan biaya usahatani semangka antara anggota tetap dan tidak tetap pada kelompok tani Ridho Lestari

Kriteria pengambilan keputusan:

a. Apabila $t_{0}>t_{0,05 / 2}$ maka $\mathrm{H} 0$ diterima, berarti tidak terdapat perbedaan nyata efisiensi penggunaan biaya usahatani semangka antara anggota tetap dan tidak tetap pada kelompok tani Ridho Lestari

b. Apabila $\mathrm{t}_{0}>\mathrm{t}_{0,05 / 2}$ maka $\mathrm{H} 0$ ditolak, berarti terdapat perbedaan nyata efisiensi penggunaan biaya usahatani semangka antara anggota tetap dan tidak tetap pada kelompok tani Ridho Lestari.

Untuk mencapai tujuan ketiga mengenai faktor-faktor yang mempengaruhi secara nyata pendapatan usahatani semangka pada kelompok tani Ridho Lestari di Desa Tembokrejo Kecamatan Muncar menggunakan model regresi linier berganda. Model regresi linier berganda digunakan apabila variabel bebas dalam model regresi mempunyai variabel bebas lebih dari satu. Persamaan model regresi linier berganda dapat diformulasikan sebagai berikut:

$$
\begin{aligned}
& \mathrm{Y}=\mathrm{a}+\mathrm{b}_{1} \mathrm{X}_{1}+\mathrm{b}_{2} \mathrm{X}_{2}+\mathrm{b}_{3} \mathrm{X}_{3}+\mathrm{b}_{4} \mathrm{X}_{4}+\mathrm{b}_{5} \mathrm{X}_{5}+\mathrm{b}_{6} \mathrm{X}_{6}+ \\
& \mathrm{b}_{7} \mathrm{X}_{7}+\mathrm{b}_{8} \mathrm{X}_{8}
\end{aligned}
$$

Keterangan:

$\mathrm{Y} \quad$ : Pendapatan $(\mathrm{Rp})$

a : Konstanta

b1b8: Koefisien regresi

$\mathrm{X} 1$ : Biaya lahan (Rp)

$\mathrm{X} 2$ : Biaya benih $(\mathrm{Rp})$

$\mathrm{X} 3$ : Biaya pupuk (Rp)

$\mathrm{X} 4$ : Biaya pestisida $(\mathrm{Rp})$

$\mathrm{X} 5$ : Biaya tenaga kerja (Rp)

X6 : Volume penjualan $(\mathrm{kg})$

$\mathrm{X} 7$ : Harga jual $(\mathrm{Rp} / \mathrm{kg})$

$\mathrm{X} 8$ : Pengalaman (tahun)

Uji asumsi klasik adalah uji statistik yang dilakukan sebelum melakukan uji regresi. Uji asumsi klasik digunakan untuk mengetahui apakah model regresi yang didapat sudah baik atau belum, uji asumsi klasik dapat dilihat sebagai berikut:

1. Normalitas

Uji normalitas merupakan uji yang digunakan untuk mengetahui kelayakan data. Uji normalitas dapat diketahui melalui hasil P-P Plot pada output SPSS. Kriteria normalitas dapat terpenuhi ketika hasil gambar yang diperoleh menunjukkan titiktitik data tersebar disekitar garis diagonal dan mengikuti arah garis diagonalnya begitupun sebaliknya. 
2. Heteroskedastisitas

Uji heteroskedastisitas yaitu suatu penyimpangan yang terjadi apabila variasi dari error-nya tidak identik. Gangguan heterokedastisitas dapat diketahui ketika pada grafik Scatterplot membentuk suatu pola tertentu yang teratur, sebaliknya homokedastisitas dapat diketahui ketika hasil grafik Scatterplot pada hasil analisis menyebar dan tidak membentuk suatu pola yang teratur.

3. Multikolinearitas

Uji multikolinearitas digunakan untuk mengetahui apakah terjadi korelasi diantara variabel-variabel bebas yang diikutsertakan dalam pembentukan model regresi. Multikolinieritas dapat diperiksa menggunakan Variance Inflation Faktor (VIF) untuk masing-masing variabel independent, yaitu jika suatu variabel independent mempunyai VIF $<10$ untuk masing-masing variabel independent maka dapat dikatakan model regresi terbebas dari multikoleniaritas

Untuk mengetahui persentase sumbangan pengaruh variabel bebas terhadap variabel terikat dapat diketahui dari koefisien determinasi $\mathrm{R}$ squere $\left(\mathrm{R}^{2}\right)$. Untuk menguji apakah keseluruhan variabel bebas secara serentak memberikan pengaruh pada variabel terikat digunakan uji $\mathrm{F}$, adapun formulasi untuk uji $\mathrm{F}$ adalah sebagai berikut: $\mathrm{F}_{0}=\frac{\text { Rata-rata Kuadrat Regresi }}{\text { Rata-rata Kuadrat Sisa }}$

Kriteria pengambilan keputusan:

a. Jika $\mathrm{F}_{0} \leq \mathrm{F}_{0,05}$ maka $\mathrm{H} 0$ diterima, artinya keseluruhan faktor-faktor yang mempengaruhi pendapatan secara serentak tidak memberikan pengaruh yang nyata terhadap pendapatan usahatani semangka pada kelompok tani Ridho Lestari

b. Jika $\mathrm{F}_{0} \leq \mathrm{F}_{0,05}$ maka $\mathrm{H} 0$ ditolak, artinya keseluruhan faktor-faktor yang mempengaruhi pendapatan secara serentak memberikan pengaruh yang nyata terhadap pendapatan usahatani semangka pada kelompok tani Ridho Lestari

Untuk mengetahui sejauh mana pengaruh masing-masing variabel bebas terhadap variabel terikat dapat digunakan uji-t dengan formulasi sebagai berikut:

$$
\text { Sbi }=\frac{\frac{b i}{\mathrm{t}_{0}=\mid \text { Sbi } i}}{\text { jumlahlahKuadratSisa }}
$$

Kriteria pengambilan keputusan:

a. Jika $\mathrm{t}_{0} \leq \mathrm{t}_{0,05}$ maka H0 diterima, artinya koefisien regresi faktor yang mempengaruhi pendapatan tidak memberikan pengaruh yang nyata terhadap pendapatan usahatani semangka pada kelompok tani Ridho Lestari dengan taraf signifikansi 5\%

b. Jika $t_{0} \leq t_{0,05}$ maka H0 ditolak, artinya koefisien regresi faktor yang mempengaruhi pendapatan memberikan pengaruh yang nyata terhadap pendapatan usahatani semangka pada kelompok tani Ridho Lestari dengan taraf signifikansi $5 \%$

\section{HASIL DAN PEMBAHASAN \\ Pendapatan Usahatani Semangka pada Anggota Tetap dan Anggota Tidak Tetap pada Kelompok Tani Ridho Lestari}

Besarnya pendapatan petani semangka di Desa Tembokrejo Kecamatan Muncar (Pd) merupakan selisih antara total penerimaan (TR) yang diperoleh dengan total biaya (TC) yang dikeluarkan oleh petani pada saat berusahatani semangka. Total penerimaan petani semangka adalah hasil dari usahatani semangka yang kemudian dijualnya sehingga memperoleh penerimaan, sedangkan total biaya adalah jumlah biaya tetap dan biaya variablel yang dikeluarkan untuk usahatani semangka. Jika penerimaan yang diperoleh petani semangka lebih besar daripada biaya yang dikeluarkannya, maka pendapatan yang diperoleh besar begitu pula sebaliknya apabila penerimaan yang diperoleh petani semangka lebih kecil daripada biaya yang dikeluarkannya, maka pendapatan yang diperoleh petani kecil dengan asumsi harga dan produksi tidak turun. Hasil analisis pendapatan usahatani semangka pada kelompok tani Ridho Lestari dapat dilihat pada Tabel 2. 
Berdasarkan Tabel 2. di bawah dapat diketahui bahwa pendapatan anggota tetap lebih tinggi daripada anggota tidak tetap. Pendapatan anggota tetap sebesar Rp 15.127.627,- per hektar per musim tanam sedangkan pendapatan anggota tidak tetap adalah sebesar Rp 9.363.509,- per per hektar per musim tanam. Hal ini terjadi karena anggota tidak tetap kelompok tani Ridho Lestari menggunakan fix cost lebih besar dibandingkan dengan anggota tetap. Perbedaan fix cost tersebut karena petani anggota tetap menggunakan lahannya sendiri sedangkan anggota tidak tetap menyewa lahan sebagai usahataninya.

Rata-rata biaya tetap (fix cost) usahatani semangka pada anggota tidak tetap lebih tinggi daripada biaya anggota tetap. Rata-rata biaya tetap (fix cost) pada anggota tidak tetap yaitu sebesar Rp. 2.573.646,5 dalam satu kali musim tanam sedangkan rata-rata biaya tetap (fix cost) pada anggota tetap kelompok tani Ridho Lestari yaitu sebesar $\mathrm{Rp}$ 522.491,67 dalam satu kali musim tanam. Hal tersebut disebabkan oleh sewa lahan yang dikeluarkan oleh petani anggota tidak tetap untuk melakukan budidaya semangka.

Biaya tetap (fix cost) usahatani semangka pada anggota tidak tetap kelompok tani Ridho Lestari lebih tinggi daripada biaya anggota tetap. Biaya tetap (fix cost) pada anggota tidak tetap yaitu sebesar Rp 5.178.005,- per hektar per musim tanam sedangkan Biaya tetap (fix cost) pada anggota tetap kelompok tani Ridho Lestari yaitu sebesar Rp 1.436.220,-per hektar per musim tanam. Hal tersebut disebabkan oleh sewa lahan yang dikeluarkan oleh petani anggota tidak tetap untuk melakukan budidaya semangka.

Biaya variabel usahatani semangka pada anggota tetap lebih tinggi daripada anggota tidak tetap. Biaya variabel usahatani semangka pada anggota tetap yaitu Rp 11.146.952,- per hektar per musim tanam sedangkan biaya variabel pada anggota tidak tetap yaitu Rp 10.432.485,- per hektar per musim tanam. Hal tersebut disebabkan oleh faktor kebiasaan petani dalam berusahatani semangka yang menyebabkan biaya variabel tinggi. Kebiasaan berusahatani setiap petani semangka berbeda-beda. Kebiasaan petani dalam menggunakan produk tertentu bisa menjadikan fanatisme produk. Ada petani yang fanatik terhadap produk pertanian tertentu misalnya insektisida Marshall untuk hama dan ada juga yang menggunakan insektisida Prevathon. Insektisida Marshal merupakan racun lambung dan kontak, artinya sistem kerja obat ini merusak lambung serangga sedangkan racun kontak berarti sistem kerja obat ini bekerja ketika serangga kontak langsung dengan tanaman yang baru disemprot obat Marshal. Insektisida Prevathon merupakan racun lambung dan kontak yang bekerja secara translaminar, artinya obat ini bisa masuk ke jaringan tanaman semangka tetapi kandungan kimia Prevathon relatif aman terhadap manusia. Kelebihan insektisida Prevathon membuat harga insektisida ini lebih mahal daripada harga insektisida Marshal.

Total penerimaan usahatani semangka pada anggota tidak tetap juga lebih tinggi daripada penerimaan anggota tetap. Penerimaan usahatani semangka pada anggota tidak tetap yaitu $\mathrm{Rp} 24.974 .000$,per hektar per musim tanam, sedangkan total penerimaan usahatani semangka pada anggota tetap yaitu Rp 27.710.800,- per hektar per musim tanam. Hal tersebut disebabkan oleh produksi semangka anggota tidak tetap lebih tinggi daripada anggota tetap. Semakin tinggi produksi semangka maka biaya yang dikeluarkan juga semakin tinggi. Apabila petani semangka bisa menekan biaya produksi maka penerimaan akan lebih tinggi. 
Tabel 2. Pendapatan Usahatani Semangka per Hektar pada Kelompok Tani Ridho Lestari pada Musim Tanam Juli 2014

\begin{tabular}{clcrr}
\hline No. & \multicolumn{1}{c}{ Uraian } & Satuan & Anggota Tetap & \multicolumn{1}{c}{ Anggota Tidak Tetap } \\
\hline 1 & Produksi & $\mathrm{Kg}$ & $10.975,33$ & $10.005,00$ \\
2 & Harga & $\mathrm{Rp} / \mathrm{kg}$ & $2.420,00$ & $2.395,00$ \\
3 & Biaya tetap & $\mathrm{Rp}$ & $1.436 .220,80$ & $5.178 .005,60$ \\
4 & Biaya variabel & $\mathrm{Rp}$ & $11.146 .952,00$ & $10.432 .485,33$ \\
5 & Total biaya & $\mathrm{Rp}$ & $12.583 .173,00$ & $15.610 .491,00$ \\
6 & Total Penerimaan & $\mathrm{Rp}$ & $27.710 .800,00$ & $24.974 .000,00$ \\
7 & Pendapatan & $\mathrm{Rp}$ & $15.127 .627,08$ & $9.363 .509,11$ \\
\hline Sumber: Data Primer Diolah Tahun 2015 & & &
\end{tabular}

Tabel 3. Hasil Analisis Uji t-test Pendapatan Usahatani Semangka per Hektar pada Kelompok Tani Ridho Lestari

\begin{tabular}{lrrrr}
\hline \multicolumn{1}{c}{ Pendapatan } & \multicolumn{1}{c}{ Rata-Rata } & \multicolumn{1}{c}{ N } & Std. Deviation & \multicolumn{1}{c}{ Std.Error Mean } \\
\hline Anggota tetap & 15127627.03 & 30 & 8820463.10268 & 1610388.86966 \\
Anggota tidak tetap & 9363509.05 & 20 & 9482659.46539 & 2120387.11721 \\
\hline
\end{tabular}

Sumber: Data Primer diolah, Tahun 2015

Tabel 4. Hasil Analisis F-hitung dan t-hitung Pendapatan Anggota Tetap dan Anggota Tidak Tetap pada Kelompok Tani Ridho Lestari

\begin{tabular}{llccccc}
\hline & F & Sig. & t & df & $\begin{array}{c}\text { Sig. (2- } \\
\text { tailed) }\end{array}$ \\
\hline Pendapatan & $\begin{array}{l}\text { Equal variances assumsed } \\
\text { Equal variances not }\end{array}$ & .000 & .983 & 2.197 & 48 & .033 \\
assumsed & & & 2.165 & 38.783 & .037 \\
\hline
\end{tabular}

Sumber: Data Primer diolah, Tahun 2015

Tabel 3. di atas menunjukkan bahwa pendapatan anggota tetap pada kelompok tani Ridho Lestari sebesar Rp 15.127.627,per hektar per musim tanam. Pendapatan anggota tidak tetap pada kelompok tani Ridho Lestari sebesar Rp 9.363.509,- per hektar per musim tanam. Selisih antara pendapatan usahatani semangka antara anggota tetap dan anggota tidak tetap pada kelompok tani Ridho Lestari sebesar $\mathrm{Rp}$ 5.764.118,- per hektar per musim tanam.

Selanjutnya untuk mengetahui apakah terdapat kesamaan varian kedua populasi (Fhitung) dan untuk mengetahui perbedaan pendapatan secara nyata antara anggota tetap dan anggota tidak tetap pada kelompok tani Ridho Lestari menggunakan (t-hitung), dapat dilihat Tabel 4.

Perbedaan pendapatan antara anggota tetap dan anggota tidak tetap pada kelompok tani Ridho Lestari secara nyata dapat diketahui melalui analisis uji beda (uji-t) untuk sampel tidak berpasangan tersebut dapat dilihat pada Tabel 4.

Berdasarkan Tabel 4. di atas dapat diketahui bahwa nilai t-hitung untuk pendapatan equal variances assumsed (asumsi kedua varian sama) adalah sebesar 2,197 dengan nilai signifikansi sebesar 0,033 . Nilai signifikansi kurang dari 0,05 (Sig. $0,033 \leq 0,05$ ) berarti hipotesis yang diajukan diterima, sehingga dapat disimpulkan bahwa terdapat perbedaan pendapatan secara nyata antara anggota tetap dan anggota tidak tetap pada kelompok tani Ridho Lestari. Hal ini selaras dengan hasil penelitian Wibawani (2001), yang menyatakan bahwa terdapat perbedaan pendapatan usahatani semangka pada strata luas lahan I dan II. 
Efisiensi Penggunaan Biaya Usahatani Semangka Pada Anggota Tetap dan Tidak Tetap Kelompok Tani Ridho Lestari

Tingkat pendapatan yang tinggi yang diterima oleh setiap petani pada usahatani semangka dapat dicapai dengan memperhatikan efisiensi biaya produksi. Penggunaan biaya produksi yang efisien akan memberikan keuntungan yang besar bagi setiap petani. Efisiensi yang tinggi dapat diperoleh dengan jalan meningkatkan produksi semangka dengan mutu yang baik dan menekan biaya produksi yang dikeluarkan petani untuk usahatani semangka. Rata-rata efisiensi penggunaan biaya pada anggota tetap lebih tinggi daripada efisiensi penggunaan biaya pada anggota tetap. Angka dari R/C rasio lebih besar sama dengan satu menunjukkan bahwa usahatani semangka anggota tetap dan anggota tidak tetap pada kelompok tani Ridho Lestari memberikan keuntungan bagi petani semangka karena rata-rata penerimaan yang diperoleh lebih besar daripada rata-rata biaya yang dikeluarkan dalam satu kali musim tanam. Hasil analisis $\mathrm{R} / \mathrm{C}$ rasio pada anggota tetap dan anggota tidak tetap kelompok tani Ridho Lestari dapat dilihat pada Tabel 5.

Tabel 5. Hasil Analisis R/C Rasio Usahatani Semangka Anggota Tetap dan Anggota Tidak Tetap pada Kelompok Tani Ridho Lestari

\begin{tabular}{clcrr}
\hline No. & \multicolumn{1}{c}{ Hasil } & Satuan & Anggota Tetap & \multicolumn{1}{c}{ Anggota Tidak Tetap } \\
\hline 1 & Total Penerimaan & $\mathrm{Rp}$ & 27.710 .800 & 24.974 .000 \\
2 & Total Biaya & $\mathrm{Rp}$ & 12.583 .173 & 15.610 .491 \\
\hline & R/C rasio & & $\mathbf{2 , 2}$ & $\mathbf{1 , 6}$ \\
\hline
\end{tabular}

Sumber: Data Primer diolah, Tahun 2015

Tabel 6. Hasil Analisis F-hitung dan t-hitung Perbedaan Efisiensi Penggunaan Biaya Anggota Tetap dan Anggota Tidak Tetap pada Kelompok Tani Ridho Lestari

\begin{tabular}{|c|c|c|c|c|c|c|}
\hline & & $\mathbf{F}$ & Sig. & $\mathbf{t}$ & df & Sig. (2-tailed) \\
\hline \multirow[t]{2}{*}{ Efisiensi } & $\begin{array}{l}\text { Equal variances } \\
\text { assumsed }\end{array}$ & .540 & .466 & 3.096 & 48 & .003 \\
\hline & $\begin{array}{l}\text { Equal variances not } \\
\text { assumsed }\end{array}$ & & & 3.170 & 44.004 & .003 \\
\hline
\end{tabular}

Sumber: Data Primer diolah, Tahun 2015

Tabel 5. di bawah menunjukkan bahwa $\mathrm{R} / \mathrm{C}$ rasio atau efisiensi penggunaan biaya pada anggota tetap lebih tinggi daripada efisiensi penggunaan biaya pada anggota tetap. Efisiensi penggunaan biaya pada anggota tetap lebih besar atau sama dengan satu $(2,2 \geq 1)$ artinya, efisiensi penggunaan biaya pada anggota tetap efisien, sedangkan efisiensi penggunaan biaya pada anggota tidak tetap lebih besar sama dengan satu $(1,6 \geq 1)$ artinya, efisiensi penggunaan biaya pada anggota tidak tetap juga efisien. Hasil R/C rasio yakni 2,2 pada anggota tetap dapat diartikan bahwa setiap penggunaan biaya sebesar Rp 1.000,- maka anggota tetap kelompok tani Ridho Lestari akan memperoleh penerimaan sebesar $\mathrm{Rp}$ 2.200,- sedangkan hasil $\mathrm{R} / \mathrm{C}$ rasio sebesar
1,6 pada anggota tidak tetap dapat diartikan bahwa setiap penggunaan biaya sebesar $\mathrm{Rp}$ 1.000,- maka anggota tidak tetap akan memperoleh penerimaan sebesar Rp 1.600,--

Selanjutnya untuk mengetahui kesamaan varian kedua populasi (Fhitung) dan untuk mengetahui perbedaan efisiensi penggunaan biaya secara nyata antara anggota tetap dan anggota tidak tetap pada kelompok tani Ridho Lestari menggunakan (t-hitung), dapat dilihat pada Tabel 6.

Total penerimaan pada anggota tetap lebih tinggi daripada total penerimaan anggota tidak tetap. Hal ini karena produksi semangka pada anggota tetap lebih tinggi dibandingkan produksi semangka pada anggota tidak tetap. Total biaya pada 
anggota tidak tetap lebih tinggi daripada anggota tetap. Hal ini karena adanya biaya tambahan pada anggota tidak tetap seperti sewa lahan. Biaya sewa lahan sangat tinggi sehingga efisiensi biaya usahatani semangka pada anggota tidak tetap lebih rendah daripada anggota tetap.

Berdasarkan Tabel 6. di atas dapat diketahui bahwa nilai t-hitung untuk efisiensi equal variances assumsed (asumsi kedua varian sama) adalah sebesar 3,096 dengan nilai signifikansi sebesar 0,003 . Nilai signifikansi kurang dari 0,05 (Sig. 0,003 $\leq$ $0,05)$ berarti bahwa hipotesis yang diajukan diterima, sehingga dapat disimpulkan bahwa terdapat perbedaan efisiensi penggunaan biaya secara nyata antara anggota tetap dan anggota tidak tetap pada kelompok tani Ridho Lestari. Hal ini selaras dengan hasil penelitian Wibawani (2001), yang menyatakan bahwa terdapat perbedaan efisiensi penggunaan biaya usahatani semangka pada strata luas lahan I dan II.

\section{Faktor-faktor yang Mempengaruhi Pendapatan Usahatani Semangka pada Kelompok Tani Ridho Lestari}

Analisis linier berganda digunakan untuk mengetahui faktor-faktor yang mempengaruhi pendapatan petani semangka pada kelompok tani Ridho Lestari. Analisis linier berganda terdiri dari variabel terikat yaitu pendapatan (Y) dan variabel bebas yang terdiri dari biaya lahan (X1), biaya benih (X2), biaya pupuk (X3), biaya pestisida (X4), biaya tenaga kerja (X5), volume penjualan (X6), harga jual (X7), dan pengalaman (X8).

Analisis regresi linier berganda dilakukan dengan menggunakan alat analisis SPSS yang bertujuan untuk memudahkan mengetahui apakah terdapat gangguan dalam analisis tersebut. Gangguan yang mungkin terjadi pada regresi linier berganda antara lain Normalitas, Hetereoskedastisitas dan Multikolinieritas. Untuk mengetahui terdapatnya gangguan dalam model regresi linier berganda maka dilakukan uji asumsi klasik berikut:

1. Uji Normalitas

Uji normalitas dilakukan untuk menguji ada tidaknya variabel pengganggu atau residual memiliki distribusi normal. Uji normalitas dapat diketahui melalui hasil grafik normal P-P plot pada output SPSS. Kriteria normalitas dapat terpenuhi ketika hasil grafik yang diperoleh menunjukkan titik-titik data tersebar di sekitar garis diagonal dan mengikuti arah garis diagonalnya. Sebaliknya, jika data tersebar jauh dari garis diagonal maka hal tersebut menunjukkan bahwa grafik tidak menunjukkan adanya pola distribusi normal atau tidak memenuhi asumsi normalitas. Hasil output SPSS faktor yang mempengaruhi pendapatan usahatani semangka pada kelompok tani Ridho Lestari menunjukkan bahwa titik-titik data tersebar di sekitar garis diagonal dan mengikuti garis diagonal, hal tersebut menunjukkan bahwa grafik pendapatan usahatani semangka pada kelompok tani Ridho Lestari dapat memenuhi asumsi normalitas.

2. Uji Heterokedastisitas

Uji heteroskedastisidas adalah varian residual yang tidak sama pada setiap pengamatan di dalam semua model regresi. Pengambilan kesimpulan ada tidaknya kasus heterokedastisitas pada model regresi dapat dilihat melalui grafikscatterplot pada output SPSS. Gangguan heterokedastisitas dapat diketahui ketika pada grafik scatterplot membentuk suatu pola tertentu yang teratur (bergelombang, melebar kemudian menyempit). Sebaliknya tidak adanya gangguan heteroskedastisidas dapat diketahui ketika hasil grafik Scatterplot pada hasil analisis menyebar di atas dan di bawah angka nol dan tidak membentuk suatu pola yang teratur. Hasil analisis regresi linier untuk faktor yang mempengaruhi tingkat pendapatan kelompok tani Ridho Lestari menunjukkan bahwa titik-titik yang ada pada grafik Scatterplot menyebar secara acak, sehingga dapat disimpulkan bahwa tidak terjadi gangguan heterokedastisitas pada model regresi linier berganda

\section{Uji Multikolonieritas}

Multiolinieritas adalah adanya hubungan linier sempurna atau mendekati sempurna antar variabel bebas dalam model regresi. Konsekuensi adanya Multikolinieritas adalah koefisien korelasi tidak menentu dan kesalahan menjadi sangat 
besar atau tidak terhingga. Nilai yang umum digunakan untuk mengetahui adanya multikolonieritas adalah tolerance $<0,1$ atau sama dengan nilai VIF (pada tabel coefficients) > 10. Hasil analisis regresi untuk pendapatan kelompok tani Ridho Lestari menunjukkan bahwa nilai tolerance $>0,1$ dan nilai VIF < 10 maka model regresi tidak terdapat gangguan multikolonieritas.

Hasil analisis pada Tabel 7. di atas menunjukkan bahwa nilai F-hitung sebesar
461,910 dengan nilai signifikansi 0,000 . Nilai signifikansi tersebut kurang dari 0,05 $(0,000 \leq 0,05)$ maka biaya lahan, biaya benih, biaya pupuk, biaya pestisida, biaya tenaga kerja, volume penjualan, harga, dan pengalaman secara bersama-sama berpengaruh nyata terhadap pendapatan usahatani semangka kelompok tani Ridho Lestari. Untuk menguji pengaruh masingmasing variabel bebas terhadap variabel terikat dilakukan pengujian (uji-t).

Tabel 7. Analisis Varian Faktor-faktor yang Mempengaruhi Pendapatan Kelompok Tani Ridho Lestari

\begin{tabular}{lrrrrr}
\hline Model & Sum of Squares & \multicolumn{1}{c}{ Df } & Mean Square & F & Sig.(0,05) \\
\hline Regression & $4.316 \mathrm{E} 15$ & 8 & $5.394 \mathrm{E} 14$ & 461.910 & $.000^{\mathrm{a}}$ \\
Residual & $4.788 \mathrm{E} 13$ & 41 & $1.168 \mathrm{E} 12$ & & \\
Total & $4.363 \mathrm{E} 15$ & 49 & & & \\
\hline
\end{tabular}

Sumber: Data Primer diolah, Tahun 2015

Tabel 8. Faktor-faktor yang Berpengaruh terhadap Pendapatan Kelompok Tani Ridho Lestari

\begin{tabular}{lrrr}
\hline Variabel bebas & Koef. Regresi & \multicolumn{1}{c}{ T } & Sig. \\
\hline Biaya_lahan & -.841 & -9.885 & $.000^{*}$ \\
Biaya_benih & -2.256 & -2.728 & $.009^{*}$ \\
Biaya_pupuk & -.340 & -.621 & .538 \\
Biaya_pestisida & -1.946 & -2.280 & $.028^{*}$ \\
Biaya_tenaga kerja & -1.053 & -5.870 & $.000^{*}$ \\
Volume_penjualan & 2609.369 & 52.710 & $.000^{*}$ \\
Harga_jual & 11203.495 & 5.845 & $.000^{*}$ \\
pengalaman & 10222.096 & .223 & .824 \\
\hline (Constanta) & -28195816.938 & & \\
Adjustred $\mathrm{R}^{2}$ Square & .987 & & \\
\hline
\end{tabular}

Sumber: Data Primer diolah, Tahun 2015

Hasil analisis pada Tabel 8. di atas menunjukkan bahwa nilai konstanta regresi linier berganda sebesar -28195816.938 hal ini berarti bahwa jika kelompok tani Ridho Lestari tidak melakukan usahatani semangka maka kelompok tani Ridho Lestari tidak akan mendapatkan (kehilangan) uang sebesar Rp 28.195.816,-. Nilai koefisien determinasi $\left(\mathrm{R}^{2}\right)$ pada anggota tetap di atas menunjukkan 0,987 berarti bahwa 98,7\% pendapatan usahatani semangka pada kelompok tani Ridho Lestari dipengaruhi oleh variabel bebas dalam model sedangkan sisanya $1,3 \%$ dipengaruhi oleh variabel lain yang tidak dimasukkan dalam model regresi. Hasil regresi linier berganda pada Tabel 8. di atas menunjukkan bahwa variabel independent (bebas) pada kelompok tani Ridho Lestari terdapat enam variabel bebas yang berpengaruh nyata terhadap pendapatan. Variabel bebas yang berpengaruh secara nyata terhadap pendapatan adalah biaya lahan (Rp), biaya benih (Rp), biaya pupuk (Rp), biaya tenaga kerja (Rp), volume penjualan ( $\mathrm{kg}$ ), dan harga jual (Rp) sedangkan biaya pupuk (Rp) dan pengalaman (Tahun) tidak berpengaruh secara nyata terhadap pendapatan. Hasil regresi menunjukkan model persamaan sebagai berikut:

$\begin{aligned} \mathrm{Y}= & -28.195 .816,938-0,841 \mathrm{X}_{1}-2,256 \mathrm{X}_{2}- \\ & 0,340 \mathrm{X}_{3}-1,946 \mathrm{X}_{4}-1,053 \mathrm{X}_{5}+ \\ & 2.609,369 \mathrm{X}_{6}+11.203,495 \mathrm{X}_{7}+ \\ & 10.222,096 \mathrm{X}_{8}\end{aligned}$


Pengaruh masing-masing variabel bebas yang mempengaruhi pendapatan pada kelompok tani Ridho Lestari di Desa Tembokrejo Kecamatan Muncar secara rinci dapat dilihat dari nilai t-hitung dengan koefisien regresinya. Nilai t-hitung tersebut adalah sebagai berikut:

1. Biaya lahan (X1)

Koefisien regresi variabel biaya lahan (Rp) pada kelompok tani Ridho Lestari sebesar -0,841 dengan tanda negatif, artinya setiap penambahan seribu rupiah biaya lahan berupa pajak lahan atau sewa lahan untuk usahatani semangka akan mengurangi pendapatan kelompok tani Ridho Lestari sebesar Rp 841,-. Dari nilai thitung yang diperoleh menunjukkan bahwa variabel biaya lahan (X1) dalam usahatani semangka memiliki t-hitung sebesar $-9,885$ dengan tingkat signifikansi sebesar 0,000 . Nilai signifikansi kurang dari probabilitas $(0,000 \leq 0,05)$ maka hipotesis yang diajukan diterima, berarti bahwa variabel biaya lahan (Rp) usahatani semangka berpengaruh secara nyata terhadap pendapatan kelompok tani Ridho Lestari. Hal ini sesuai dengan hasil penelitian Wibawani (2001), yang menyatakan bahwa luas lahan berpengaruh nyata terhadap pendapatan usahatani semangka pada strata luas lahan I dan II.

Biaya lahan (Rp) usahatani semangka berpengaruh secara nyata terhadap pendapatan kelompok tani Ridho Lestari. Hal ini disebabkan oleh biaya sewa lahan yang tinggi untuk usahatani semangka di Desa Tembokrejo Kecamatan Muncar. Biaya sewa lahan usahatani semangka sebesar Rp. 4.337.500,- per MT/Ha. biaya sewa lahan dilakukan oleh anggota tidak tetap kelompok tani Ridho Lestari.

2. Biaya benih (X2)

Koefisien regresi variabel biaya benih pada kelompok tani Ridho Lestari adalah sebesar -2,256 dengan tanda negatif, artinya setiap penambahan seribu rupiah biaya benih untuk usahatani semangka maka akan mengurangi besarnya pendapatan kelompok tani Ridho Lestari sebesar Rp 2.256,-- Dari nilai t-hitung yang diperoleh menunjukkan bahwa variabel biaya benih dalam usahatani semangka memiliki t-hitung sebesar -2,728 dengan tingkat signifikansi sebesar 0,009. Nilai signifikansi kurang dari probabilitas $(0,009 \leq 0,05)$ maka hipotesis yang diajukan diterima, berarti bahwa variabel biaya benih dalam usahatani semangka berpengaruh nyata terhadap pendapatan kelompok tani Ridho Lestari. Hal ini tidak sesuai dengan hasil penelitian Wibawani (2001), yang menyatakan bahwa biaya bibit tidak berpengaruh nyata terhadap pendapatan usahatani semangka pada strata luas lahan I dan II.

Variabel benih berpengaruh nyata terhadap pendapatan kelompok tani Ridho Lestari, Hal ini karena biaya benih non-biji tinggi. Biaya benih semangka pada anggota tetap sebesar Rp. 2.406.500,- per MT/Ha, sedangkan biaya benih semangka pada anggota tidak tetap sebesar Rp. 2.398.583,per MT/Ha. Benih semangka terbagi menjadi dua yaitu benih semangka berbiji dan semangka non-biji. Jenis benih semangka berbiji berbeda dengan semangka non-biji. Semangka berbiji dibutuhkan bunganya untuk penyerbukan sedangkan semangka non-biji dibutuhkan buahnya.

3. Biaya pupuk (X3)

Koefisien regresi variabel biaya pupuk dalam usahatani semangka pada kelompok tani Ridho Lestari adalah sebesar $-0,340$ dengan tanda negatif, artinya setiap penambahan seribu rupiah biaya pupuk untuk usahatani semangka akan mengurangi besarnya pendapatan kelompok tani Ridho Lestari sebesar Rp 340,-. Dari nilai t-hitung yang diperoleh menunjukkan bahwa variabel biaya pupuk memiliki t-hitung sebesar 0,621 dengan tingkat signifikansi sebesar 0,538 . Nilai signifikansi lebih besar dari probabilitas $(0,538>0,05)$ maka hipotesis yang diajukan ditolak, berarti bahwa variabel biaya pupuk dalam usahatani semangka tidak berpengaruh nyata terhadap pendapatan kelompok tani Ridho Lestari. Hal ini sesuai dengan hasil penelitian Wibawani (2001), yang menyatakan bahwa biaya pupuk berpengaruh nyata terhadap pendapatan usahatani semangka pada strata luas lahan I dan II.

Variabel biaya pupuk dalam usahatani semangka tidak berpengaruh nyata terhadap pendapatan kelompok tani Ridho Lestari. Hal ini disebabkan oleh biaya pupuk 
semangka tinggi tetapi tidak sesuai kebutuhan. Biaya pupuk pada anggota tetap sebesar Rp. 1.941.300,- per MT/Ha, sedangkan biaya pupuk pada anggota tidak tetap sebesar Rp. 1.869.516,- per MT/Ha. Petani lebih menekankan pada pupuk anorganik daripada pupuk organik setiap musim tanam. Biaya pupuk organik pada anggota tetap sebesar Rp. 349.333,- per MT/Ha, sedangkan biaya untuk pupuk organik pada anggota tidak tetap sebesar Rp. 223.333,- per MT/Ha.

4. Biaya pestisida (X4)

Koefisien regresi yang dimiliki oleh variabel biaya pestisida dalam usahatani semangka pada kelompok tani Ridho Lestari adalah sebesar -1,946 dengan tanda negatif, artinya setiap penambahan seribu rupiah biaya pestisida untuk usahatani semangka akan mengurangi besarnya pendapatan kelompok tani Ridho Lestari sebesar Rp 1.946,-. Dari nilai t-hitung yang diperoleh menunjukkan bahwa variabel biaya pestisida memiliki t-hitung sebesar -2,280 dengan tingkat signifikansi 0,028 . Nilai signifikansi kurang dari probabilitas $(0,028 \leq 0,05)$ maka hipotesis yang diajukan diterima, berarti bahwa variabel biaya pestisida dalam usahatani semangka berpengaruh nyata terhadap pendapatan kelompok tani Ridho Lestari. Hal ini sesuai dengan hasil penelitian Wibawani (2001), yang menyatakan bahwa biaya obat berpengaruh nyata terhadap pendapatan usahatani semangka pada strata luas lahan I dan II.

Variabel biaya pestisida dalam usahatani semangka berpengaruh nyata terhadap pendapatan anggota tetap kelompok tani Ridho Lestari. Hal ini karena biaya pestisida untuk usahatani semangka tinggi. Biaya pestisida yang tinggi diakibatkan oleh adanya hama kutu kebul (Bemisia tabaci). Petani anggota tetap yang rugi akibat hama kutu kebul sebanyak 3 orang sedangkan petani anggota tidak tetap yang rugi sebanyak 5 orang. Kutu kebul merupakan media penular (vektor) penyakit tanaman. Penyakit yang dibawa oleh kutu kebul adalah virus gemini. Virus gemini menyebabkan tanaman keriting dan kerdil kemudian tidak berbuah. Biaya pestisida yang dikeluarkan anggota tetap sebanyak
Rp. 676.833,- per MT/Ha sedangkan biaya pestisida yang dikeluarkan anggota tidak tetap sebanyak Rp. 657.333,- per MT/Ha.

5. Biaya tenaga kerja (X5)

Koefisien regresi variabel biaya tenaga kerja dalam usahatani semangka pada kelompok tani Ridho Lestari adalah sebesar $-1,053$ dengan tanda negatif, artinya setiap penambahan seribu rupiah biaya tenaga kerja untuk usahatani semangka akan mengurangi besarnya pendapatan anggota tetap kelompok tani Ridho Lestari sebesar Rp 1.053,-. Dari nilai t-hitung yang diperoleh menunjukkan bahwa variabel biaya tenaga kerja dalam usahatani semangka memiliki t-hitung sebesar $-5,870$ dengan tingkat signifikansi sebesar 0,000 . Nilai signifikansi kurang dari probabilitas $(0,000 \leq 0,05)$ maka hipotesis yang diajukan diterima, berarti bahwa variabel biaya tenaga kerja dalam usahatani semangka berpengaruh nyata terhadap pendapatan kelompok tani Ridho Lestari. Hal ini tidak sesuai dengan hasil penelitian Yulianto (2005), yang menyatakan bahwa biaya tenaga kerja tidak berpengaruh nyata terhadap pendapatan usahatani semangka.

Biaya tenaga kerja berpengaruh nyata terhadap pendapatan usahatani semangka pada kelompok tani Ridho Lestari. Hal ini karena usahatani semangka membutuhkan banyak tenaga kerja. Kebutuhan tenaga kerja pada usahatani semangka misalnya mengatur percabangan, penyerbukan, membajak dan mencangkul lahan. Biaya tenaga kerja usahatani semangka pada anggota tetap sebesar Rp. 4.820.666,- per MT/ha sedangkan biaya tenaga kerja pada anggota tidak tetap sebesar Rp. 4.244.000,per MT/Ha. Tenaga kerja yang dibutuhkan petani pada usahatani semangka tidak hanya dipenuhi oleh keluarga petani semangka sendiri. Petani semangka banyak yang menggunakan tenaga kerja di luar keluarga sehingga petani harus memberi upah kepada tenaga kerja luar keluarga tersebut yang telah membantu dalam usahatani semangka.

\section{Volume penjualan (X6)}

Koefisien regresi variabel volume penjualan dalam usahatani semangka pada kelompok tani Ridho Lestari adalah sebesar 
2.609,369 dengan tanda positif, artinya setiap penambahan satu kilogram volume penjualan semangka maka akan meningkatkan pendapatan kelompok tani Ridho Lestari sebesar Rp. 2.609,-. Dari nilai t-hitung yang diperoleh menunjukkan bahwa variabel volume penjualan dalam usahatani semangka memiliki t-hitung sebesar 52,710 dengan tingkat signifikansi 0,000 . Nilai signifikansi kurang dari probabilitas $(0,000$ $\leq 0,05)$ maka hipotesis yang diajukan diterima, berarti bahwa variabel volume penjualan dalam usahatani semangka berpengaruh nyata terhadap pendapatan kelompok tani Ridho Lestari.

Variabel volume penjualan dalam usahatani semangka berpengaruh nyata terhadap pendapatan kelompok tani Ridho Lestari. Hal ini karena volume penjualan atau hasil produksi semangka pada saat penelitian tinggi. Volume penjualan semangka pada anggota tetap sebesar 10.975 $\mathrm{Kg} / \mathrm{Ha}$, sedangkan volume penjualan semangka pada anggota tidak tetap kelompok tani Ridho Lestari sebesar 10.005 $\mathrm{Kg} / \mathrm{Ha}$. Semakin tinggi volume penjualan semangka akan semakin tinggi pula pendapatan yang akan diperoleh petani pada kondisi harga yang tetap, sebaliknya semakin sedikit volume penjualan semangka maka pendapatan akan semakin berkurang pada kondisi harga tetap.

7. Harga jual (X7)

Koefisien regresi variabel harga jual dalam usahatani semangka pada kelompok tani Ridho Lestari adalah sebesar 11.203,495 dengan tanda positif, artinya setiap penambahan satu rupiah harga jual semangka akan meningkatkan besarnya pendapatan kelompok tani Ridho Lestari sebesar Rp 11.203,-. Dari nilai t-hitung yang diperoleh menunjukkan bahwa variabel harga jual dalam usahatani semangka memiliki t-hitung sebesar 5,845 dengan tingkat signifikansi sebesar 0,000 . Nilai signifikansi kurang dari probabilitas $(0,000$ $\leq 0,05)$ maka hipotesis yang diajukan diterima, berarti bahwa variabel harga jual semangka berpengaruh nyata terhadap pendapatan kelompok tani Ridho Lestari.

Variabel harga jual dalam usahatani semangka berpengaruh nyata terhadap pendapatan kelompok tani Ridho Lestari. Hal ini karena harga jual pada musim panen semangka tinggi. Harga jual semangka pada anggota tetap kelompok tani Ridho Lestari sebesar Rp. 2.420,- per kilogram, sedangkan harga jual semangka pada anggota tidak tetap sebesar Rp. 2.395,- per kilogram. Harga semangka yang tinggi disebabkan oleh kurangnya pasokan semangka di beberapa daerah karena panen semangka yang tidak bersamaan.

8. Pengalaman (X8)

Koefisien regresi variabel pengalaman dalam usahatani semangka pada kelompok tani Ridho Lestari adalah sebesar 10.222,096 dengan tanda positif, artinya setiap penambahan satu tahun pengalaman usahatani semangka akan meningkatkan pendapatan kelompok tani Ridho Lestari sebesar Rp. 10.222,-. Dari nilai t-hitung yang diperoleh menunjukkan bahwa variabel pengalaman dalam usahatani semangka memiliki t-hitung sebesar 0,223 dengan tingkat signifikansi sebesar 0,824 . Nilai signifikansi lebih dari probabilitas $(0,824>$ $0,05)$ maka hipotesis yang diajukan ditolak, berarti bahwa variabel pengalaman dalam usahatani semangka tidak berpengaruh nyata terhadap pendapatan kelompok tani Ridho Lestari.

Variabel pengalaman usahatani semangka tidak berpengaruh nyata terhadap pendapatan kelompok tani Ridho Lestari. Hal ini karena lama pengalaman berusahatani semangka belum tentu menghasilkan produksi semangka yang maksimal pada musim tanam berikutnya. Pengalaman usahatani semangka pada anggota tetap selama 9,5 tahun sedangkan pengalaman usahatani semangka pada anggota tidak tetap selama 5,6 tahun.

\section{KESIMPULAN}

1. Terdapat perbedaan nyata pendapatan antara anggota tetap dan anggota tidak tetap pada kelompok tani Ridho Lestari di Desa Tembokrejo Kecamatan Muncar Kabupaten Banyuwangi.

2. Terdapat perbedaan nyata efisiensi penggunaan biaya antara anggota tetap dan anggota tidak tetap pada kelompok tani Ridho Lestari di Desa Tembokrejo 
Kecamatan Muncar Kabupaten Banyuwangi.

3. Faktor-faktor yang berpengaruh nyata terhadap pendapatan usahatani semangka pada kelompok tani Ridho Lestari yaitu biaya lahan $(\mathrm{Rp})$, biaya benih $(\mathrm{Rp})$, biaya pestisida (Rp), biaya tenaga kerja (Rp), volume penjualan (kg) dan harga jual (Rp/Kg)

\section{DAFTAR PUSTAKA}

Ashari, Sumeru. 1995. Hortikultura Aspek budidaya. Jakarta: Universitas Indonesia (UI-Press)

Asri. 2012. Study Komparatif Pendapatan Petani Semangka dan Petani Padi (Study Kasus Desa Pilang dan Desa Sidodadi Kecamatan Masaran Kabupaten Sragen. SM. Vol 1 (1) : 80-155

Hasan, Iqbal. 2012. Pokok-pokok Materi Statistik 2 (Statistik Inferensif). Jakarta: Bumi Aksara

Irianto, Agus. 2004. Statistik Konsep Dasar dan Aplikasinya. Jakarta: Kencana

Kalie, Moehd. Baga. 2002. Bertanam Semangka. Jakarta: Penebar Swadaya

Prajnanta, Final. 1999. Agribisnis Semangka Non-Biji. Jakarta: Penebar Swadaya

Setiawan dan Kusrini. 2010. Ekonometrika. Yogyakarta: Penerbit Andi

Soetriono et. al., 2003. Pengantar Ilmu pertanian. Malang: Bayumedia

Suratiyah, ken. 2011. Ilmu Usahatani. Jakarta: Penebar Swadaya

Wibawani. 2001. Analisis Biaya, Pendapatan dan Faktor-faktor Sosial Ekonomi yang Mempengaruhi Pendapatan Usahatani Semangka. Skripsi. Jember: Jurusan Sosial Ekonomi Pertanian Fakultas Pertanian Universitas Jember. 